\title{
PARASITE FAUNA MONITORING OF MATRINXÃ Brycon amazonicus (SPIX \& AGASSIZ, 1829) RAISED IN AN INTENSIVE HUSBANDRY SYSTEM IN A STREAM CHANNEL IN THE STATE OF AMAZONAS, BRAZIL
}

\author{
ANDRADE, S. M. S. and MALTA, J. C. O. \\ Laboratório de Parasitologia e Patologia de Peixes - LPP, Coordenação de Pesquisas em Biologia Aquática - CPBA, \\ Instituto Nacional de Pesquisas da Amazônia - INPA, C. P. 478, CEP 69011-970, Manaus, Amazonas, Brazil \\ Correspondence to: Sanny Maria Sampaio de Andrade, Laboratório de Parasitologia e Patologia de Peixes - LPP, \\ Coordenação de Pesquisas em Biologia Aquática - CPBA, Instituto Nacional de Pesquisas da Amazônia - INPA, \\ C. P. 478, CEP 69011-970, Manaus, Amazonas, Brazil, e-mail: sanny@interlins.com.br \\ Received May 6, 2005 - Accepted September 20, 2005 - Distributed November 1, 2006
}

(With 1 figure)

\begin{abstract}
The matrinxã, Brycon amazonicus, is one of the main species being used for aquaculture and fishery activities in the Amazonian region, yet little is known about the parasites that cause its diseases. The present study monitored parasite fauna infesting an intensive husbandry system in a stream channel. The collections were carried out monthly from September, 1997 to January, 1998. Water quality parameters, fish removal procedures, as well as biometry and anaesthetic data were observed in order to monitor the management conditions. Of the 80 sampled fish, 71 (89\%) were infested with four Monogenoidea species (Anacanthorus spiralocirrus, Jainus amazonensis, Tereancistrum kerri and Trinibaculum brazilensis), 12 (15\%) one of Nematoda Spirocamallanus inopinatus, and three (3.75\%) with the Copepoda Ergasilus bryconis. Monogenoidea presented the highest prevalence and intensity of infestation. The KruskallWallis non-parametric variance analysis showed a significant difference $(\mathrm{P}<0.05)$ in the monthly parasite indexes of A. spiralocirrus, J. amazonensis and T. brazilensis, however no significant difference $(\mathrm{P} \geq 0.05)$ was detected for T. kerri. Evaluation of the management conditions pointed out that monthly capture anaesthesia and hauling procedures may have been responsible for some of the clinical signals such as loss of scales, erosion and no pigments on the caudal fin and cornea opacity, which were the most frequently found injuries in husbandry.
\end{abstract}

Keywords: Brycon amazonicus, parasites, ichthyosanitary management, fish-husbandry.

\section{RESUMO}

\section{Monitoramento da fauna parasitológica e das condições de manejo do matrinxã Brycon amazonicus (Spix \& Agassiz, 1829) em sistema de cultivo intensivo em canal de igarapé no Estado do Amazonas}

O matrinxã Brycon amazonicus, é uma espécie amplamente cultivada na região Amazônica, entretanto, as doenças parasitárias são praticamente desconhecidas. Este estudo teve como objetivo monitorar mensalmente a fauna parasitológica e as condições de manejo em sistema de cultivo intensivo em canal de igarapé. As coletas foram realizadas mensalmente, durante os meses de setembro de 1997 a janeiro de 1998. O monitoramento das condições de manejo foi realizado observando-se os parâmetros de qualidade de água, procedimentos de despesca, biometrias e anestesia. Oitenta (80) peixes foram amostrados, dos quais, 71 (89\%) encontravam-se parasitados com quatro espécies de monogenóideos (Anacanthorus spiralocirrus, Jainus amazonensis, Tereancistrum kerri e Trinibaculum brazilensis), 12 (15\%) com o nematóide Spirocamallanus inopinatus e três $(3,75 \%)$ com o ergasilídeo Ergasilus bryconis. Os monogenóideos apresentaram os maiores valores de prevalências e intensidades de infestação. A análise de variância não 
paramétrica de Kruskall-Wallis revelou uma diferença significativa $(\mathrm{P}<0,05)$ nos índices parasitários mensais de A. spiralocirrus, J. amazonensis e T. brazilensis, porém para T. kerri não foi detectado diferença significativa $(\mathrm{P}>0,05)$. A avaliação das condições de manejo indicaram que os procedimentos mensais de captura, anestesia e transporte podem ter sido responsáveis por alguns dos sinais clínicos observados durante o cultivo. Os mais freqüentes foram: perda de escamas, erosão e despigmentação da nadadeira caudal e opacidade de córnea.

Palavras-chave: Brycon amazonicus, parasitas, manejo ictiosanitário, piscicultura.

\section{INTRODUCTION}

Matrinxã, Brycon amazonicus (Spix \& Agassiz, 1829) synonym of $B$. erythroptherum (Cope, 1872) is a species with migratory behaviour, which synchronises its movements with water level fluctuations and is found in several Amazonian landscape biotypes, such as "várzea" (floodplain inundated by white water rivers) and "igapó" (floodplain inundated by black water rivers) forests, streams and rapids. Thus, it may be found in the lower Negro and Solimões rivers (VillacortaCorrêa, 1987).

Although there is a high demand for juveniles, the husbandry of the species is still limited by the lack of more thorough knowledge of the factors concerning its biology, (such as nutritional demands, behaviour, reproduction, etc.) and its management in husbandry systems. This hampers the supply of juveniles to the producers within the region (Andrade et al., 2001).

Little is also known about the diseases and parasites attacking matrinxã both in wild and husbandry environments, and in general, these may also be considered limiting factors in the development of husbandry systems. The published studies regarding this species were conducted on fish from a wild environment and are mostly made up of taxonomic descriptions or studies on their parasite fauna (Andrade, 2000).

Parasite investigations conducted on B. amazonicus specimens of captured in wild and husbandry system environments showed this species to be infested with. Protozoa, Peritrichia mobilinia (Mendonça, 1994); Monogenoidea Anacanthorus spp. (Sanchez, 1981); Copepoda, Ergasilus sp. and E. bryconis (Sanches, 1981; Thatcher, 1981; Varella, 1985), Lernaea sp. (Ceccarelli, 1988) and Argulidae, Argulus chicomendesi Malta \& Varella, 2000 (Malta \& Varella, 2000).
Pizango-Paima (1997) who carried out a study on the feeding and body composition of B. amazonicus found copepoda and isopoda Braga sp., infesting its oral cavity, threenematoidea species, Spirocamallanus inopinatus Travassos, 1929 (11 males and 53 females), Cucullanus sp. (5 males and 13 females) and Rabdochona sp., parasitizing its pyloric caeca. Prevalence and intensity of infection were $(0.04 \%$ and 1$)$ for Braga sp. and S. inopinatus (13.8\% and 5); Cucullanus sp. (3.1\% and 3 ) and Rabdochona sp. (0.4\% and 1) respectively.

Andrade et al. (2001) examined a sample of 136 juveniles (some still with their yolk sac, length ranging from 0.8 to $5 \mathrm{~cm}$ ) of matrinxã from a wild environment. They found 49 (36\%) to be infested with trematoda metacercaria; $32(23.5 \%)$ with Nematoda S. inopinatus; 26 (19\%) with Monogenoidea Jainus amazonensis Kritsky, Thatcher \& Kayton, 1980; 3 (2\%) with protozoa Trichodina sp.; two (1.5\%) with Cestoda and one $(0.7 \%)$ with the Acanthocephala Echinorhynchus sp.

Acquiring matrinxã fingerlings in the wild is a common procedure in the region. Presently, some fish culture stations are producing fingerlings of this species in order to be able to meet the demand required by the husbandry. However, when these fish are collected from the wild environment, it is necessary to find out about their health conditions before being introduced into husbandry systems, since they possess a large diversity of parasites in their wild environment. These parasites may become pests in confined husbandry systems, if there are no proper management procedures being carried out on the species (Andrade et al., 2001).

Several of the above mentioned parasite species, such as Monogenoidea, Branchiura, Acanthocephala and Copepoda, may be considered potential pests in husbandry systems, if they are present in high infesting rates. A. chicomendesi is 
the only species associated to matrinxã mortality in intensive husbandry so far (Malta \& Varella, 2000).

According to studies carried out by Rolim (1995); Fracalossi (1997) and Andrade \& Ferraz (1999), the profile of the fish husbandry managers in the state of Amazonas is represented by small rural producers and semi intensive and intensive husbandry systems are predominant. The present study is the first one of this kind being developed on an intensive husbandry system in a stream channel in the state.

\section{MATERIAL AND METHODS}

Parasite fauna monitoring of B. amazonicus was carried out on a highland stream channel at a private estate $17 \mathrm{~km}$ from Manaus, Amazonas, Brazil. The stream was widened and the exceeding sand and organic matter were removed. The stream was sectioned into a series of enclosures made with $1 \mathrm{~cm}$ mesh plastic-screened wood frameworks and sand/cement-filled synthetic fibre bags. The selected stretch on the steam was divided into two fishpens. In the first one $(60 \mathrm{~cm}$ deep and presenting a $70 \mathrm{~m}^{2}(14 \times 5)$ water surface $)$ 30 matrinxã reproducers were introduced right by the inlet. The second one $(55 \mathrm{~cm}$ deep and with a $100 \mathrm{~m}^{2}$ water surface) was where the parasite fauna was monitored. According to Arbeláez-Rojas et al. (2002) this intense aquaculture system has a strong water flow, which goes through a channel, similar to that of aquaculture in raceways. A small $1 \mathrm{~m}$ high dam was built for the purpose of raising the natural stream's flow level and forming a smallsized reservoir.

The juveniles which were used were captured in the wild and kept at INPA's Fish-culture Station. When they reached about $15 \mathrm{~cm}$ in fork-length and $110 \mathrm{~g}$ in weight they were transferred to the stream channel where they were cultured for a period of 5 months. The stocking density was $10 \mathrm{fish} / \mathrm{m}^{2}$ or $1.3 \mathrm{~kg} / \mathrm{m}^{3}$. Fish were fed on extruded feed, twice a day, ad libitum.

Biometries were performed monthly and the feeding was suspended for $24 \mathrm{~h}$ prior to adopting this procedure. Fish were removed with a meshed "nylon" net (12 mm between knots). Anaesthesia was done with $0.4 \mathrm{~mL} / \mathrm{L}$ of 2 phenoxyetanol (Sygma, St. Louis, EUA). From a population of
1,000 individuals, nearly 100 fish were removed every month for the biometry procedures and then put back into the stream. From this total, 16 fish sub-samples were removed for 5 months, totalling 80 fish for the parasite analysis. Pathogen detection samplings were according to the Clers (1994) table, which shows that pathogens with a minimum of $3.5 \%$ prevalence may be detected in 80 fish. Specimens were placed into an aerated polyethylene box until it was time to be hauled. Then, they were taken to INPA's Fish Pathology and Parasitology Laboratory in $60 \mathrm{~L}$ plastic bags with aerated water in an eight fish per bag density. In the laboratory, the fish were kept in a constantly aerated $500 \mathrm{~L}$ asbestos cement box without being fed for a period of up to $48 \mathrm{~h}$. Necropsy, a specimen examination, parasite collection and preparation and techniques were described in Ferraz (1995) and Andrade (2000).

Parasite indexes such as prevalence, intensity, mean intensity and abundance, were expressed according to Bush et al. (1997). The monogenoidea monthly parasite index quantification was analysed through Kruskall-Wallis non-parametric variance analyses, according to Aragort \& Moreno (1997).

Host and parasite species samples were deposited in the Invertebrate Collection (Platyhelminthes collection) and in the National Research Institute of the Amazon Fish Collection. Jainus amazonensis (INPA 385), Spirocamallanus inopinatus (INPA 387), Anacanthorus spiralocirrus (INPA 386) and Brycon cephalus (INPA 15902) were deposited in a liquid medium in flasks with $70 \%$ alcohol. Trinibaculum brazilensis (INPA $388 \mathrm{a}-\mathrm{b})$ and Tereancistrum kerri (INPA 399 a-c) were deposited on permanent slides using the Malmberg method.

\section{RESULTS}

The monthly capture, biometry and hauling procedures provide the appearance of injuries such as scale loss and haemorrhages in some specimens. The occurrence of tail fin erosion was also recorded. The clinical signs shown in the fish are presented by absolute frequency in Table 1 .

From the 80 fish in the stream system that underwent necropsies, $71(89 \%)$ were infested with Monogenoidea, 12 (15\%) with Nematoda and $3(3.75 \%)$ with Copepoda. A heart blood smear 
slide analyses tested negative for blood parasites in the 20 examined fish.

Monogenoidea from Dactylogyridae were found on gill and skin scrapes in temporary slides. A greater infestation was noticed on the right side of the gill. Four species were recorded: Ancyrocephalinae (Jainus amazonensis; Tereancistrum kerri Kritsky,
Thatcher \& Kayton, 1980 and Trinibaculum brazilensis Kritsky, Thatcher \& Kayton, 1980), Anacanthorinae (Anacanthorus spiralocirrus Kritsky, Thatcher \& Kayton, 1979).

The monthly variation of the prevalence and mean intensity of all species Monogenoidea are presented in Fig. 1. The species T. brazilensis

TABLE 1

Absolute frequency of the clinical signs observed in Brycon amazonicus specimens in the period they were being intensively raised in a stream-channel

\begin{tabular}{|l|c|}
\hline \multicolumn{1}{|c|}{ Clinical Signs } & Frequency \\
\hline Outer & - \\
\hline Pale friable gill & 8 \\
\hline Haemorrhaged red spot in the gills & 2 \\
\hline Diffuse haemorrhage in the caudal fin & 2 \\
\hline Caudal fin with no pigments & 14 \\
\hline Caudal fin erosion & 18 \\
\hline Injury on the caudal peduncle & 11 \\
\hline Haemorrhaged red spot in the eyeball & 7 \\
\hline Cornea opacity & 20 \\
\hline Loss of scales & 23 \\
\hline Inner & - \\
\hline Pale friable liver & 46 \\
\hline
\end{tabular}
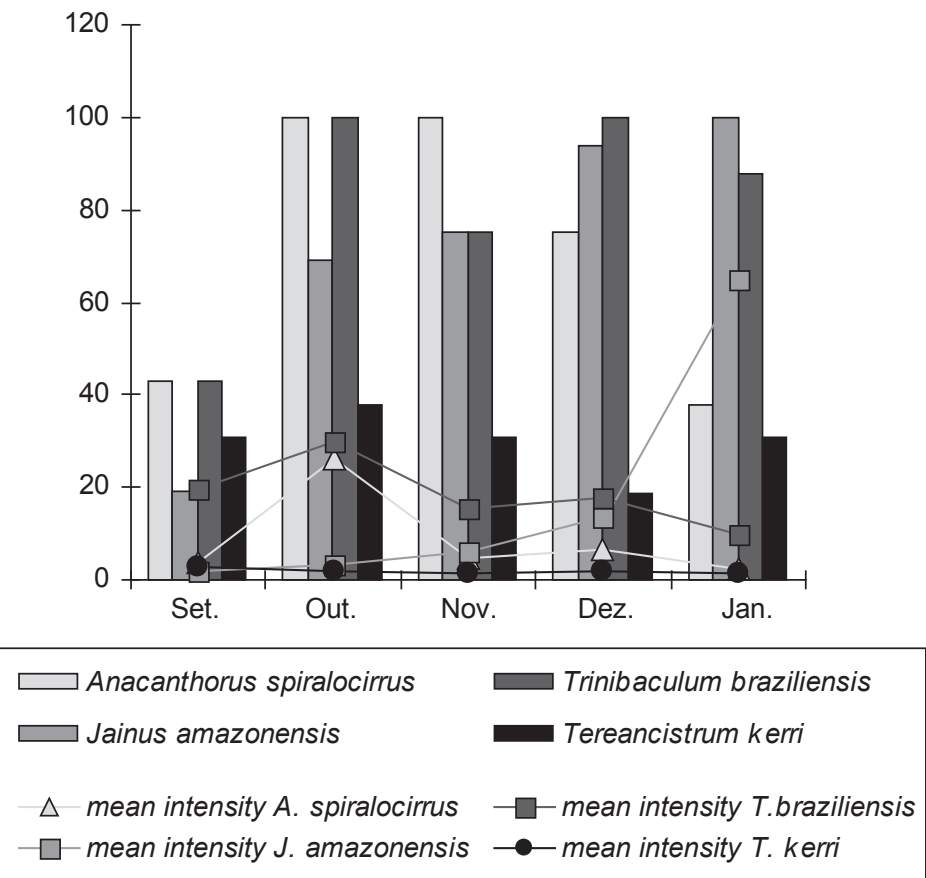

Fig. 1 - Monthly variation of the prevalence and mean intensity of all species of Monogenoidea. 
presented a higher mean prevalence in the culture $(81 \%)$ and was followed by two species A. spiralocirrus $(71 \%)$, J. amazonensis $(71 \%)$ and T. kerri (30\%). The four species of monogenoids occurred every month. The monthly prevalence of each species is presented in Table 2.

Kruskall-Wallis variance analyses showed there was a $5 \%$ level significant difference between mean intensities and the abundance of species A. spiralocirrus, T. brazilensis and J. amazonensis $(\mathrm{P}<0.05)$. The mean intensity and abundance of the species $T$. kerri was statistically equal throughout all the months ( $\mathrm{P}>0.05)$ (Tables 3 and 4$)$.

The internal parasitological exam recorded the occurrence of the Nematoda $S$. inopinatus in the anterior portion of the intestine of matrinxã. Nematoda was the second most prevalent parasite group presenting low prevalence throughout the culture. Intensity, mean intensity and abundance indexes were also low for this species (Table 5).
The Copepoda E. bryconis presented the lowest prevalence of the three parasite groups. This only occurred in the months of October and November, having a prevalence of 6.25 and 12.5, respectively. Intensity ( 1 and 1$)$, mean intensity ( 1 and 1$)$ and mean abundance (0.06 and 0.12 ) were also low (Table 6).

\section{DISCUSSION}

Fish culture systems in continuous flow series usually present uneven water quality, that is, the limnological parameter quality decreases throughout the current flow. This generally occurs due to the increasing metabolic residues in the water of the enclosures (Wheaton, 1985). In spite of it being a continuous flow in a series system, water quality variations were not present in the enclosures throughout this study. This fact might be due to the constant water renewing and siting

TABLE 2

Prevalence of the four species of Monogenoidea infesting Brycon amazonicus specimens in the period they were being intensively raised in a stream-channel.

\begin{tabular}{|l|c|c|c|c|}
\hline \multicolumn{1}{|c|}{ Month } & $\begin{array}{c}\text { Anacanthorus } \\
\text { spiralocirrus }\end{array}$ & $\begin{array}{c}\text { Trinibaculum } \\
\text { brazilensis }\end{array}$ & Tereancistrum kerri & Jainus amazonensis \\
\hline September & 43 & 43 & 31 & 19 \\
\hline October & 100 & 100 & 38 & 69 \\
\hline November & 100 & 75 & 31 & 75 \\
\hline December & 75 & 100 & 19 & 94 \\
\hline January & 38 & 88 & 31 & 100 \\
\hline Total Prevalence (\%) & 71 & 81 & 30 & 71 \\
\hline
\end{tabular}

TABLE 3

Kruskall-Wallis variance analysis of the mean intensity indexes among Monogenoidea species infesting Brycon amazonicus specimens during the period they were being intensively raised in a stream-channel.

\begin{tabular}{|c|c|c|c|c|c|c|c|c|c|c|c|c|}
\hline \multirow[t]{2}{*}{ Month } & \multicolumn{2}{|c|}{ A. spiralocirrus } & \multirow{2}{*}{$\pm \mathbf{S E}$} & \multicolumn{2}{|c|}{ T. braziliensis } & \multirow[t]{2}{*}{$\pm \mathbf{S E}$} & \multicolumn{2}{|c|}{ T. kerri } & \multirow[t]{2}{*}{$\pm \mathbf{S E}$} & \multicolumn{2}{|c|}{ J. amazonensis } & \multirow[t]{2}{*}{$\pm \mathbf{S E}$} \\
\hline & I & MII & & I & MII & & I & MII & & I & MII & \\
\hline Sept. & $1-5$ & 4 & \pm 0.61 & $1-52$ & 15 & \pm 7.37 & $1-6$ & 3 & \pm 0.83 & $1-3$ & 2 & \pm 0.57 \\
\hline Oct. & $10-54$ & 25 & \pm 2.85 & $2-83$ & 27 & \pm 5.91 & $1-3$ & 2 & \pm 0.36 & $1-9$ & 2 & \pm 0.78 \\
\hline Nov. & $1-12$ & 4 & \pm 0.76 & 2-39 & 9 & \pm 3.88 & $1-2$ & 1 & \pm 0.24 & $1-16$ & 5 & \pm 1.44 \\
\hline Dec. & $2-18$ & 5 & \pm 1.54 & $4-48$ & 15 & \pm 3.0 & $1-3$ & 2 & \pm 0.57 & $1-62$ & 9 & \pm 3.81 \\
\hline Jan. & $1-6$ & 1,5 & \pm 0.79 & $1-30$ & 7 & \pm 2.51 & $1-2$ & 1 & \pm 0.24 & $5-149$ & 57 & \pm 12.9 \\
\hline $\mathrm{P}$ & & $=0.000^{*}$ & & & 0.0340 & & & $=0.249$ & & & 0.0001 & \\
\hline
\end{tabular}

$\mathrm{P}=0.05 ;$ *Differences significant; \pm SE -Mean standard error; MII - Mean intensity of infestation; and I- Intensidade. 
TABLE 4

Kruskall-Wallis variance analysis of the mean abundance indexes among Monogenoidea species infesting Brycon amazonicus specimens in the period they were being intensively raised in a stream-channel.

\begin{tabular}{|l|c|c|c|c|c|c|c|c|}
\hline Month & $\begin{array}{c}\text { Mean } \\
\text { abundance } \\
\text { A. spiralocirrus }\end{array}$ & \pm SE & $\begin{array}{c}\text { Mean } \\
\text { abundance } \\
\text { T. brazilensis }\end{array}$ & \pm SE & $\begin{array}{c}\text { Mean } \\
\text { abundance } \\
\text { T. } \text { kerri }\end{array}$ & \pm SE & $\begin{array}{c}\text { Mean } \\
\text { abundance } \\
\text { J. amazonensis }\end{array}$ & \pm SE \\
\hline Sept. & 1.6 & \pm 0.52 & 8.6 & \pm 3.99 & 0.9 & \pm 0.43 & 0.3 & \pm 0.22 \\
\hline Oct. & 25 & \pm 2.85 & 27 & \pm 5.91 & 0.8 & \pm 0.28 & 1.5 & \pm 0.65 \\
\hline Nov. & 4 & \pm 0.76 & 6 & \pm 3.36 & 0.4 & \pm 0.18 & 4 & \pm 1.28 \\
\hline Dec. & 3 & \pm 1.35 & 15 & \pm 3.01 & 0.3 & \pm 0.22 & 9 & \pm 3.67 \\
\hline Jan. & 0.81 & \pm 0.38 & 5.5 & \pm 2.34 & 0.4 & \pm 0.18 & 57 & \pm 12.98 \\
\hline P & $=0.0001^{*}$ & & $=0.0001^{*}$ & & $=0.8140^{*}$ & & $=0.0001^{*}$ & \\
\hline
\end{tabular}

$\mathrm{P}=0.05 ;$ *Differences significant; and $\pm \mathrm{SE}-$ Mean standard error.

TABLE 5

Infesting indexes of Spirocamallanus inopinatus, a parasite found on Brycon amazonicus specimens in the period they were being intensively raised in a stream-channel.

\begin{tabular}{|l|c|c|c|c|}
\hline Month & Prevalence $(\%)$ & Intensity & Mean intensity $( \pm$ SE) & Mean Abundance $( \pm$ SE) \\
\hline September & 18.7 & $1-3$ & $2.0( \pm 0.16)$ & $0.3( \pm 0.22)$ \\
\hline October & - & - & - & - \\
\hline November & 12.5 & $1-3$ & $1.5( \pm 0.5)$ & $0.1( \pm 0.13)$ \\
\hline December & 18.7 & $1-3$ & $2.0( \pm 0.57)$ & $0.3( \pm 0.22)$ \\
\hline January & 25 & $1-3$ & $1.7( \pm 0.47)$ & $0.4( \pm 0.22)$ \\
\hline
\end{tabular}

\pm SE- Mean standard error.

TABLE 6

Infesting indexes of Ergasilus bryconis, a parasite found on Brycon amazonicus specimens in the period they were being intensively raised in a stream-channel.

\begin{tabular}{|l|c|c|c|c|}
\hline Month & Prevalence (\%) & Intensity & Mean intensity \pm SE & Mean abundance \pm SE \\
\hline September & - & - & - & - \\
\hline October & 6.25 & 1 & 1 & $0.06( \pm 0.06)$ \\
\hline November & 12.50 & 1 & 1 & $0.12( \pm 0.08)$ \\
\hline December & - & - & - & - \\
\hline January & - & - & - & - \\
\hline
\end{tabular}

\pm SE- Mean standard error.

of this system in a wild relatively small highland stream environment.

Stream water physical chemical parameters showed to be satisfactory for the studies species and did not visually affect the system's water quality which was probably due to the husbandry having been done in a wild environment.

The in series enclosure systems demand greater prophylactic care in order to minimise the occurrence of diseases, due to the water flowing from one enclosure to another (Wheaton, 1985; Grant, 1993). The kind of equipment used for capturing together with management procedures bring about a strong effect on the fish's outer appearance. The occurrence of injuries caused by physical damage caused by management practices can often be seen. (Grant, 1993; Wedemeyer, 1997; Pavanelli et al., 1998). During this work, the 
fish were submitted to mechanical stress during the capture, biometry and hauling procedures on a monthly basis. The aggressive behaviour of matrinxã may have contributed to the appearance of scale loss and haemorrhages during the hauling, since some animals presented no such traces before this procedure.

According to Kristjansson et al. (1995), the degree of occurrence of scale loss and other injuries is usually more related to improper management and use of inadequate equipment, than to the occurrence of some disease. In this work, scale loss occurred on 23 of the 80 sampled fish. The occurrence of haemorrhages was less frequent and was recorded in three regions: gills (2), eye (7) and caudal fin (2). The appearance of these traces might be associated to physical or chemical traumas (traumatic damages from the fishing equipment, problems with the anaesthetic procedure, water quality or from being struck by other individuals). The appearance of these injuries harms the fish defence system, leaving them more inclined to acquiring secondary infections by bacteria or fungi, in case they remained in the culture system.

Diseases in fish can appear in a variety of clinical signs. The normal aspects of an organ may vary strongly between the same and different species and it is only possible to generalise a few clinical signs (Collins, 1993).

Cornea opacity, friable gill and liver, which may be related to pos-morten alterations or problems with the anaesthesia, were recorded on some specimens in this work. Friable gills may also indicate anaemia, infection by parasites, bacteria or viruses. However, although this pathology can be associated to infestation by parasites, this was not ascertained in this study due to their small number. Cornea opacity was recorded on the fish after being captured, anaesthesia and hauling procedures and it could be the fish's response to post- anaesthesia stress or $\mathrm{O}_{2}$ depletion during the hauling. Early, caudal peduncle injuries and fin erosion were also recorded. The occurrence of fin erosion and injuries on the peduncle are probably associated to the attack by other fish in the enclosures or to traumatic action from the fishing gear while being captured, followed by secondary bacteria invasion.

Eight species of Monogenoidea: four of Ancyrocephalinae (Trinibaculum brazilensis, Jainus amazonensis, Tereancistrum kerri and
T. ornatus) and four of the Anacanthorinae (Anacanthorus brevis, A. elegans, A. kruidenieri and A. spiralocirrus) (Thatcher, 1991), were described for B. erythropterum (= B. amazonicus). In this work, the Monogenoidea were the parasites which presented the highest prevalence, occurring on $89 \%$ of the examined fish. Four species were recorded, Jainus amazonensis, Tereancistrum kerri, Trinibaculum brazilensis and Anacanthorus spiralocirrus.

Cerfontaine $(1896,1898)$ apud Fernando \& Hanek (1976) were some of the first to establish that some parasites prefer specific infesting sites, confirming this phenomenon with the monogenoid, Diclidophora denticulata, a gill parasite of Gadus virens. Hanek (1973) apud Fernando \& Hanek (1976) studied the spatial distribution of seven Monogenoidea species, noticing a higher abundance on the anterior and middle part of the gill arches. A trend for the Monogenoidea to become attached to different gill filament sites was found in this work.

A. spiralocirrus and T. kerri occurred in the intermediary portion of the gill filaments, nevertheless the A. spiralocirrus was quite larger. Trinibaculum brazilensis attached itself to basal regions (near the gill rakers) whereas $J$. amazonensis occurred in the gill filament. Every species exploited a specific micro-habitat, apart from J. amazonensis, which was not found colonising any particular site, maybe due to its increasing infestation levels in the culture.

Differences in the prevalence rates may be attributed to the competition for the byotype in the gill. Silan \& Maillard (1990) found that the teleost Dicentrarchus labrax was often infested with the monogenoid Diplectanum aequans, which showed high prevalence, while the Monogenoidea Diplectanum laubieri was present on few fish. The authors attributed these differences to the fact that $D$. laubieri with $D$. aequans was the same byotype.

Trinibaculum brazilensis monthly and mean prevalence values were the highest almost every month and it was the species which presented the highest mean prevalence (Table 4). There were no conflicting prevalence rate differences between the species, except for T. kerri, which presented the lowest prevalence, intensity and abundance rates throughout the culture. The low T. kerri incidence showed that $A$. spiralocirrus, prevailed over the 
T. kerri population, on account of occupying the same byotype (gill filament intermediate portion).

Trinibaculum brazilensis, as well as having the highest prevalence also showed the highest intensity of infestation and abundance (Tables 4 and 5). This points out that the byotype occupying exclusivity may have contributed to its proliferation, since it was the only species exploiting the area close to the gill rakers. This species was only surpassed in the last month (January) of farming by $J$. amazonensis, which presented the highest, intensity mean intensity and abundance indexes in a period characterised by the occurrence of rains in the region.

Aragort \& Moreno (1997) found the highest parasite indexes of Anacanthorus spatulatus Kritsky, Thatcher \& Kayton, 1979 and Linguadactyloides brinkmanni Thatcher \& Kritsky, 1983 on tambaqui in rainy periods. The authors concluded that wet climate conditions influenced the parasite load increase of these species by providing favourable conditions for reproduction of the Monogenoidea. The increase in the J. amazonensis population in January reported in this work might have been influenced by the climatic conditions. The J. amazonensis proliferation peaks occurred during December and January coinciding with the heaviest rainy period.

The effect of the environmental conditions on the variation of the parasite indexes is not generalised, apparently varying with the parasite species. A few species show no infesting pattern associated to climatic fluctuations (Aragort \& Moreno, 1997). The findings from this work showed that, in spite of the climatic conditions having influenced the J. amazonensis intensity and abundance rates, there was no marked tendency found for the other species.

Belmont-Jégu (1992) studied the composition of the community of gill Monogenoidea in Serrasalmidae fish in environments in the Amazonian basin rapids and found heterogeneity in the infestation rate. The author attributed these differences to the environment of the rapids where the hosts were collected from, which hampered the dispersion of the oncomiracidium.

The Monogenoidea species considered in this work presented no even parasite indexes throughout the months. Despite the farming environment not being characterised by a rapids system, the increased flowing of the water in the stream during the rainy periods might have contributed to demographic differences occuring in the infrapopulations of these parasites.

Aragort \& Moreno (1997) used the KruskallWallis test to find whether there were significant differences in the parasite indexes of the two Monogenoidea species during the collecting months and noticed a significant difference in the distribution of these parasites on Colossoma macropomum (Cuvier, 1818).

The Kruskall-Wallis test confirmed that the differences visualised in the indexes of this work were statistically significant for A. spiralocirrus, T. brazilensis and J. amazonensis. However, T. kerri presented an even pattern throughout all the months, with no significant differences being detected on its parasite indexes. The significant difference on the J. amazonensis monthly intensity and abundance variation might be associated to the increase in parasites in January. This species presented the lowest infesting indexes in the beginning of the farming process, developing an increasing pattern as the months went by, surpassing the remaining species in the last month. Kruskall-Wallis analysis of variance values A. spiralocirrus indicated the October was statistically different from the others. Intensity and abundance levels were higher during that month.

Pizango-Paima (1997) recorded the occurrence of three species of Nematoda on adult B. amazonicus from the wild (S. inopinatus, Cucullanus sp. and Rhabdochona sp.) In this work, there was only the occurrence of S. inopinatus.

These parasites, when occurring in large infestations may bring about a severe inflammatory reaction and anaemia (Thatcher, 1991). Its occurrence on small fish may occlude the intestine, causing mortality or affecting growth (Pavanelli et al., 1998). Despite no pathogen having been detected on the examined specimens at the sampling time, it is important to highlight that the nature of its attachment may cause occlusion and perforation of the intestine in young individuals. This may possibly lead to anaemia due to the haematohogous behaviour of this species.

The prevalence and intensity recorded by Pizango-Paima (1997) in the wild environment were, S. inopinatus (13.8\% and 5), 
Cucullanus sp. (3.1\% and 3) and Rhabdochona sp. $(0.4 \%$ and 1$)$, respectively. This work showed that for S. inopinatus, a prevalence of $14.9 \%$ and an intensity of 1-3 were found.

Varella(1985)noticed that the B. erythropterus (= B. amazonicus) adults were infested by the Copepoda E. bryconis on individuals from both wild and fish-culture environments. There were higher infesting indexes recorded on farmed fish than on those from the wild. The mean prevalence and intensity found for farming environments were $80 \%$ and 52 on the 25 sampled fish. In this work, the parasite indexes were very low, with a record of infestation mean prevalence and intensity of $3.75 \%$ and 0.4 respectively on 80 fish.

Culture systems possessing fast flow rates prevent the direct life cycle of a few parasites. Systems presenting slower flow rates allow the build up of parasite infesting stages in the culture (Southgate, 1993). The matrinxã parasite fauna in the stream system did not show very high infesting indexes, pointing out that this system must hinder the life cycle of some parasites. Andrade et al. (2001) noticed that of the 136 B. amazonicus fingerlings examined in the wild, $36 \%$ were infested with Trematoda metacercariae, $23.5 \%$ with Nematoda S. inopinatus, $19 \%$ with Monogenoidea J.amazonensis, $2 \%$ with the protozoaTrichodina sp., $1.5 \%$ with Cestoda larval instars and $0.7 \%$ with the Acanthocephala Echinorhynchus sp.

The region's only matrinxã farming system showing mortality problems was recorded at the fish-culture station of the Instituto Nacional de Pesquisas da Amazônia in 1980. A great epizooty of Argulus sp. infesting Brycon erythropterum (= B. amazonicus) was recorded. At that time, the enclosures were emptied and all fish were slaughtered (Benetton \& Malta, 1999). Later, the species was described as being A. chicomendesi Malta \& Varella, 2000. It was the very first record of a parasite species causing mortality in farmed fish in the Amazon (Malta \& Varella, 2000).

Several studies have already recorded the pathogenic potential and consequently the mortality that the Monogenoidea can cause in intensive husbandry systems. In spite of them having been the most prevalent group in the farming, there was no report of mortality associated to these parasites in this study.
However, farming procedures recorded the occurrence of clinical signs on the examined fish, which might be related to traumatic actions, anaesthetic outcome, and being struck by other fish.

Some preventing measures should be followed in order to be able to farm B. amazonicus in a stream channel. The fish generations should be kept separate, that is, there should be no direct contact between young and adult fish, since the latter may carry parasites, which may be harmful to the former. If there is a need to, the young should be placed in the first enclosure and the adults in those following, since the current flow will make it difficult for the parasites to travel from the adults to the young. The same fishing equipment used in different groups of fish should be avoided, so as not to harm their health. In case this cannot be done, the equipment should be disinfected prior to being used again. Sites in the stream system that may be for other things other than fish farming should not be used, and selecting a site with a safe water supply with springs of water within the estate is recommendable. Therefore, it should be emphasised that preventive measures in a farming system have a significant effect on the occurrence of epizootic outbreaks, and it is much easier to keep the diseases away from the culture than to take them away.

Acknowledgments - We are indebted to Capes/The British Council/INPA Convention, responsible for partial funding of the "Amazonian Aquaculture Development" project to which this work was attached. To INPA's Aquaculture Research Coordination and especially to Jorge Fin for his valuable help and remarks.

\section{REFERENCES}

ARBELÁEZ-ROJAS, G., FRACALOSSI, D. M. \& FIM, J. D. I., 2002, Composição corporal de tambaqui, Colossoma macropomum, e matrinxã, Brycon cephalus, em sistemas de cultivo intensivo em igarapé, e semi-intensivo, em viveiros. Rev. Bras. de Zootecnia, 31(3): 1059-1069.

ANDRADE, S. M. S. \& FERRAZ, E. O., 1999, Avaliação das condições de manejo e doenças em cultivos de peixes no Estado do Amazonas. pp. 250-257. In: Memorians Acuicultura en armonia com el ambiente. Aquacultura' 99. Puerto de La Cruz, Venezuela.

ANDRADE, S. M. S., 2000, Monitoramento da fauna parasitológica e das condições de manejo do matrinxã Brycon cephalus (Günther, 1869) em sistema de cultivo intensivo em igarapé no Estado do Amazonas. Dissertação de Mestrado, Instituto Nacional de Pesquisas da Amazônia/ 
Fundação Universidade do Amazonas. Manaus, Amazonas. 100 p.

ANDRADE, S. M. S., MALTA, J. C. \& FERRAZ, E., 2001, Fauna parasitológica de alevinos de matrinxã, Brycon cephalus (Günther, 1869) coletados nos rios Negro e Solimões, na Amazônia Central. Acta Amazonica, 31(2): 263-273.

ARAGORT, W. C. \& MORENO, L. G., 1997, Indices epidemiologicos de trematodos monogeneticos en branquias de Colossoma macropomum bajo cultivo. Acta Biologica Venezuelana, 17(1): 1-8.

BELMONT-JÉGU, E., 1992, Monogenoidea (Platyhelminthes) indicadores da biogeografia histórica de três espécies de Mylesinus (Characoidei, Serrasalmidae) na Bacia Amazônica. Dissertação de Mestrado, Instituto Nacional de Pesquisas da Amazônia/Fundação Universidade do Amazonas. Manaus, Amazonas. 76p.

BENETTON, M. L. F. N. \& MALTA, J. C. O., 1999, Morfologia dos estágios de naúplios e copepodito I de Perulernaea gamitanae Thatcher \& Paredes, 1985 (Crustacea: Cyclopoida: Lernaeidae), parasita do tambaqui Colossoma macropomum (Cuvier, 1818), (Characiformes: Serrasalmidae). Acta Amazonica, 29(1): 97-121.

BUSH, A. O., LAFFERTY, K. D., LOTZ, J. M. \& SHOSTAK, A. W., 1997, Parasitology meets ecology on its own terms: Margolis et al. Revisited. Jour. of Parasitology, 83(4): 575-583.

CECCARELLI, P. S., 1988, Susceptibilidade à infestação de Lernaea Linnaeus (Copepoda: Lernaeidae), em diferentes espécies de peixes cultivados no CEPTA e testes de infestação do pacu Piaractus mesopotamicus em laboratório. Bol. Técnico do CEPTA, 1(2): 31-35.

COLLINS, R., 1993, Principles of diseases diagnosis. pp. 6989. In: Brown, L. (Ed.). Aquaculture for veterinarians: fish husbandry and medicine. Pergamon Press, New York, USA.

CLERS, S., 1994, Sampling to detect infections and estimate prevalence in aquaculture. Pisces Press University of Stirling, Stirling, Scotland. 58p.

FERNANDO, C. H. \& HANEK, C., 1976, Gills. Habitats. Part II. pp. 209-226. In: Kennedy, C. R. (Ed.). Ecological aspects of parasitology. North Holland Publishing CompanyAmsterdam. Oxford, UK.

FERRAZ, E., 1995, Studies on parasites of ornamental fish from South America with particular reference to their pathogenicity and potential for transfaunation. $\mathrm{Ph}$. $\mathrm{D}$. Thesis. University of Stirling, Institute of Aquaculture, Stirling, Scotland. 404p.

FRACALOSSI, D. M., 1997, Panorama da Aquicultura na Região Norte. Anais do I Workshop Internacional de Aquicultura, São Paulo, SP, Brasil. p. 7-13.

GRANT, A., 1993, Basic husbandry on fish farms. pp. 31-41. In: Brown, L. (ed.). Aquaculture for Veterinarians: fish husbandry and medicine. Pergamon Press, New York, USA.

KRISTJANSSON, B. A., HARDARSON, T. H., SKULASON, S. \& SVEINSSON, T., 1995, Effects on growth of Arctic charr of handling, anaesthesia and repeated formalin bathing shortly after first exogenous feeding. Jour. of Fish Biology, 46: 163-165.
MALTA, J. C. O. \& VARELLA, A., 2000, Argulus chicomendesi sp. n. (Crustacea: Argulidae) parasita de peixes da Amazônia brasileira. Acta Amazonica, 30(3): 481-498.

MENDONÇA, J. O. J., 1994, Criação de espécies do gênero Brycon no CEPTA/IBAMA. pp. 31-48. In: Anais do seminário sobre criação de espécies do gênero Brycon. Pirassununga, São Paulo, Brasil.

PAVANELLI, G. C., EIRAS, J. C. \& TAKEMOTO, R. M., 1998, Doenças de Peixes: Profilaxia, Diagnóstico e Tratamento. EDUEM, Universidade Estadual de Maringá, Maringá, Brasil. 264p.

PIZANGO-PAIMA, E. G., 1997, Estudo da alimentação e composição corporal do matrinxã Brycon cephalus (Günther, 1869) (Characiformes, Characidae) na Amazônia Central. Dissertação de Mestrado, Instituto Nacional de Pesquisas da Amazônia/Fundação Universidade do Amazonas, Manaus, Amazonas. 71 p. Sanchez, V. P. 1981. Enfermedades parasitarias del "sabalo cola roja" Brycon erythropterum y "gamitana" Colossoma macropomum de la zona de Iquitos. IFS. Acuicultura III, 10: 261-269.

ROLIM, P. R.,1995, A infra-estrutura básica para criação de peixes no Amazonas. pp. 7-16. In: Val, A. e Honczaryck, A. (Eds.), Criando Peixes na Amazônia. Instituto Nacional de Pesquisas da Amazônia, Manaus, Brasil.

SANCHEZ, V. P. 1981, Enfermedades parasitarias del "sabalo cola roja" Brycon erythropterum y "gamitana" Colossoma macropomum de la zona de Iquitos. IFS. Acuicultura III, 10: 261-269.

SILAN, P. Y. \& MAILLARD, C., 1990, Comparative structures and dynamics of some population of helminths, parasites of fishes: the sea bass Diplectanum model. Ac. Oecologica, 11(6): 857-874.

SOUTHGATE, P., 1993, Disease in Aquaculture. pp. 91-129. In: Brown, L. (ed.). Aquaculture for Veterinarians: fish husbandry and medicine. Pergamon Press, New York, USA.

THATCHER, V. E., 1991, Amazon Fish Parasites. Amazoniana, 11(3/4): 263-572.

VARELLA, A. M. B., 1985, O ciclo biológico de Ergasilus bryconis, Thatcher, 1981 (Crustacea: Poecilostomatoida, Ergasilidae) parasita das brânquias do matrinxã, Brycon erytropterum (Cope, 1872) e aspectos de sua ecologia. Ed. Universitária, Natal, Brasil. 99p.

VILLACORTA-CORREA, M. A., 1987, Crescimento do matrinxã, Brycon cephalus (Günther, 1869) no baixo Rio Negro, seus afluentes e no baixo Rio Solimões. Dissertação de Mestrado, Instituto Nacional de Pesquisas da Amazônia/ Fundação Universidade do Amazonas, Manaus, Amazonas. 124p.

WHEATON, F. W., 1985, Aquacultural Enginering. Univ. Maryland, Maryland, USA. 708p.

WEDEMEYER, G. A., 1997, Effects of rearing conditions on the health and physiological quality of fish in intensive cultere. pp. 35-71. In: Iwama, G. K.; Pickering, A. D.; Sumpter, J. P.; Schreck, C. B (Eds.). Fish Stress and Health in Aquaculture. Experimental Biology Seminar séries, University of Cambridge, Cambridge, USA. 